\title{
Graham Scott
}

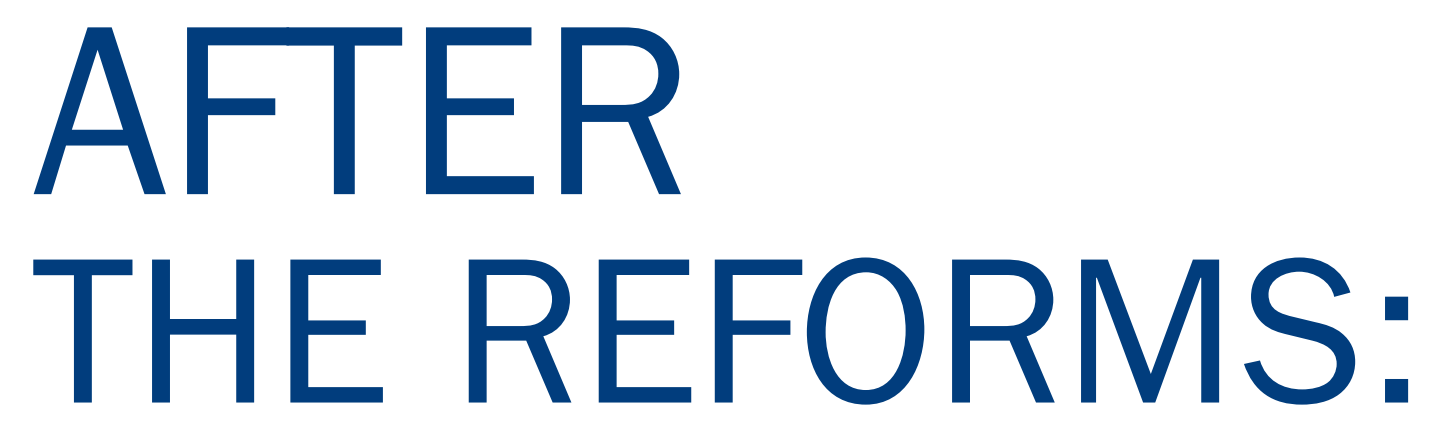

\section{Some Questions}

\section{About the State} of the State in

\section{New Zealand}

Graham Scott is a distinguished former public servant in New Zealand. He served in the Prime Minister's Department in the late 1970s and joined the Treasury in 1981, serving as secretary to the Treasury between 1986 and 1993. He played a key role in developing advice to the fourth Labour government and subsequent National government on a wide range of issues, including public sector reform. Since 1993 he has been an adviser to many governments and organisations around the world. He was chair of the Health Funding Authority between 1996 and 2000.
This article comments on some of the current challenges facing the New Zealand public sector. I reflect mostly on the change relating to the core state services, to some Crown entities and some state-owned enterprises. I will also make brief comments regarding the relevance of possible constitutional change to the state sector. ${ }^{\mathrm{i}}$

$\mathrm{I}$ $\mathrm{t}$ interests me that the prevailing view of those past reforms as seen from the State Services Commission ( $\mathrm{SSC})$ is that:

The positive aspects of these reforms are known including increased transparency, accountability, efficiency and better service in many areas. More recent reforms have placed greater emphasis on results and the way in which government agencies work together. (SSC, 2005)

The inside view from the top gives the impression therefore that there is a plan in place and good progress is being made towards the six state sector development goals laid down by the SSC. My outsider's task in this article is to question this.

My views about the reforms based on the State Sector Act and the Public Finance Act were spelled out in a speech to a similar conference as this in 1999 sponsored by the SSC (Scott, 1999), and in my book on the subject in 2001 (Scott, 2001). In these, I pointed to issues I thought needed attention, to lessons that should not be forgotten and to challenges I saw ahead. Some of these points are noted below as a basis for comments on where the systems that were subjected to those reforms are today:

- The need for clarity in the roles, rights, responsibilities, freedoms and accountabilities of the people in the key positions associated with public institutions; 
- The need to turn managing for outcomes into a routine practice of public management and not individual cases driven by unusually talented management teams;

- Learning from the hard edges of accountability and seeking to refine and develop systems through experience and careful evaluation of results, both good and bad;

- The need for public managers, led by the SSG, to lift performance in the endless effort to ensure that the pool from which top appointments are drawn is deep and well prepared for high performance in demanding top jobs;

- The need to improve the capability of ministers to play their roles effectively through informed advice, improving the processes they work within and through selection and personal development;

- The need for robust, imaginative and thoughtful strategic management;

- The need for effective coordination on cross-cutting issues within government, including partnerships with the private and community (NGO) sectors;

- The need to strengthen policy focus and capability in public sector agencies; and

- The need for high ethical standards and professional skills to pervade the state sector. resources - has fallen from its average of $2.0 \%$ p.a. in the period 1988-2000 and 2.3\% in 1992-2000, to an average of $0.9 \%$ from 2000 to 2006. After a long slide down the ranks of the OECD in terms of income per capita, the acceleration in productivity after the reforms in the 1980s and 1990s arrested this decline and we began to claw our way back. But on current performance it looks impossible to reach the average of the OECD income per capita in the foreseeable future, and emigration statistics indicate that people are voting with their feet at a time of record low unemployment.

Most economists would agree that for a small open economy the interactions between activities that are exposed to international market forces and those that are protected from them are crucial to overall economic performance. A business in the exposed sector has to compete with the prices and quality standards of the best international producers. It has to match the pace of innovation of its global competitors.

The protected sectors bring to the exposed sectors both advantages that can help beat the competition and disadvantages that handicap it. For example, a great education system that produces well-trained technical staff is an advantage; a tax burden that exceeds the benefits of stateprovided services is a disadvantage.

The state is a very large component of

After 20 years of experimenting the government should try again to get to grips with the real issues... and chart a course that is more promising than the one we are on. the protected sectors and it has profound effects on the health of exposed sectors through its policies. While government is a necessary part of the solution to disturbing productivity statistics, it is also likely to be a very big contributor to the problem.

The economic ministries as a group will be falling short of the ambitious

I will use cases about the economy, regulation, state enterprises, hospitals and some cross-cutting issues to illustrate why I think these lessons that I thought we learned up to 2001 are still relevant when considering the performance of state administration today and some appear to have been forgotten.

\section{The economy}

Following the economic and state sector reforms in the mid1980s and the early 1990s there was a measurable uplift in productivity trends and hence growth prospects, and a marked improvement in the resilience of the economy to shocks (see Whitehead, 2005). However, the long-term growth outlook has been dented by a drop-off in productivity growth in recent years that worries most observers. I suggest that the state has played a part in this.

The present government began with a view that previous methods of economic management had been too handsoff and that a more interventionist approach across the spectrum of policies was the answer. The results thus far are disappointing.

The trend growth in multi-factor productivity - the improvement in efficiency on both capital and labour performance goals in their strategy documents if they do not provide a very clear view for the government about productivity and what should be done about it - including possibly unwelcome advice about the performance of the state.

The Australian Productivity Commission has a distinguished track record of research and perhaps could, within the spirit of CER, accept a commission to contribute to a study of New Zealand's productivity record.

\section{Regulation}

In the last eight years the philosophy and implementation of regulation has shifted from light-handed to heavy-handed regulation. The former emphasises analysis by expert tribunals, information, incentives, and a concern for the balance of risks between taking action when it is not justified and not taking it when it is. Intervention by ministers is at arm's length, formal and transparent. The latter is based more on direct intervention by ministers observing less formality and distance in their business with the heads of regulatory commissions.

Some of the evidence about the effect of this change is worrying. For example, Bronwyn Howell of Victoria Univer- 
sity suggests that the shift in the regulatory regime coincided with a deterioration in performance in telecommunications in terms of technological progress, pricing and efficiency (see Howell, 2007). As Howell argues, we have gone 359 degrees through light-handed and back to heavy-handed regulation. She says it is not at all clear that the light-handed approach failed, and that there are substantial regulatory risks to heavyhanded industry specific regulation, especially in a small market undergoing rapid technological change. The current approach may be putting the appearance of competition ahead of national benefit in terms of efficiency in using these resources. If this is so, it has serious implications for national productivity.

In the electricity industry the evidence of things going wrong is more apparent. Whatever the circumstances of the resignation of the electricity commissioner, Roy Hemingway, if the content of an affidavit he has recently provided in the High Court is taken at face value there has been behaviour by ministers that is not consistent with an orderly process of market regulation.

I think Mr. Hemingway made a mistake in assuming he had much independence as a commissioner in the first place. In my submission to the select committee hearing on the bill that created the Electricity Commission, I showed that the commissioner was in effect only advisory to the minister (see Scott, 2004). But the faults in this legislation go much deeper than that. It breaches most of the principles that in my view are important for high performing public organisations, as my submission documents show in detail. It is careless regarding the conventions of Parliament about the delegation of its regulatory powers, and ignored auditorgeneral and Treasury guidelines on setting fees and charges. It overrides the duties of Transpower's directors in respect of investments, so it is scarcely surprising that the meltdown was over Transpower's investments, as the conflict was built into the legislation.

This is a good example of ministers blaming officials for their own mistakes - a practice that has grown rapidly in recent years. They created a central planning agency for the industry and it is failing for the reasons central planning of complex industries usually does.

After 20 years of experimenting the government should try again to get to grips with the real issues, which are about integrating investments in generation and transmission, and chart a course that is more promising than the one we are on. If we don't, then the next time there is an interruption to supply we will go off on another wild goose chase in a fog of shallow political responses. There is a lot more here than regulating for competition. A harmonisation of environmental policies and economic policies in this industry seems out of reach at present. The ban on building base-load thermal stations for ten years is already stressing the transmission system.

The Commerce Commission considered the benefits of regulation of the gas pipeline industry in 2004. Having identified that the net public benefits of regulating some of the suppliers of pipeline services were negative, it nevertheless resolved to recommend regulating them on the basis of benefits to the users of the services from regulating the producers. In simple terms the commission decided that, although government control would produce an overall negative effect on the economy in terms of the efficiency of use of these assets and reduced investment in pipelines, it would recommend regulation of these firms because of benefits in terms of short-term transfers to their customers (see Commerce Commission, 2004). This is a clear example of a preference for redistribution over productivity and investment. But why should commercial firms using pipelines be given any weight when it comes to welfare policies particularly when there is a cost in terms of national welfare? There is evidence that even for the users the benefits were only short term, and in the longer term became negative.
Across a wider spread of regulation than these utilities there is broad support in political and business circles for the idea that regulations are not properly evaluated before they are implemented. Sectional interests are able to get regulations that suit their interests without concern for the wider public interest. The requirement for regulatory impact statements to accompany proposals to Cabinet for regulations is widely ignored, and they have been judged by an independent review as of poor quality (see Tasman Economics, 2001).

One response to this has been the drafting of a Regulatory Responsibility Bill, which has gained enough support across Parliament to get a hearing. I hope this will be a signal to officials involved in regulatory activities to lift their game.

It would be hard to find a serious economist who would not put a review of regulatory polices on the short list of things to be considered in an examination of the productivity performance of the economy. The Treasury should take a leading role in reviewing regulation both because it is not directly involved in the processes being criticised, and also as a consequence of its mandate to advise governments on economic matters.

\section{State enterprises}

State-owned enterprises comprise 39 companies with $\$ 12$ billion in assets, which means their efficiency has a major impact on the economy as a whole, particularly because much 
of the investment is in utilities used across the economy.

The principles of the State-Owned Enterprises (SOE) Act of 1986 have proved remarkably durable and achieved what was hoped for them by the government of that time. But that was then. Now we have a different policy for how to govern and manage these enterprises in a condition of long-term government ownership. The designers of the original model thought that, over time, performance would go slack for reasons that would be hard to counteract. Among these were the lack of capital market disciplines and the weaknesses inherent in public sector processes for setting strategic directions for commercial businesses, monitoring and reacting to results. There was also concern that, once the first flush of enthusiasm was past, these enterprises would have trouble attracting highly qualified directors in sufficient numbers and patronage appointments would rise in number. The answer seen at the time was privatisation. However, it was recognised early on that network utilities were going to provide particular problems about how to implement competition policy and how to coordinate various industrywide functions like the wholesale electricity market and the national transmission system. by the state prohibits privatisation as a mechanism for investors to compete to put assets to more productive use. This prohibition likely explains the conclusion of a large international literature that, on average over time, state ownership leads to worse business performance than private ownership. It follows that in general there should be an $a$ priori reason, for state ownership of assets. Such reasons are usually associated with essential public utilities where private solutions are unsatisfactory for whatever reasons, or where non-economic objectives are involved. Other reasons for state ownership can arise in developing countries with immature markets.

Section 7 of the SOE Act allows for the government to enter an agreement with an SOE to give effect to a noncommercial objective. But it is rarely used, as ministers don't appreciate the transparency and it will likely require an appropriation in the budget. It is however, an important provision for transparency and should be used as intended. The fiscal curse of developing countries around the world is undisclosed contingent liabilities favouring political interests through covert influence on state enterprises. We need to be very careful not to allow this to develop here again as it did in the early 1980 s with catastrophic fiscal consequences.

The authorities have recognised recently

\section{Air New Zealand is not an SOE but a public} company in majority public ownership. The shareholder can influence strategy and direction only through the means established in general company law.

It is hard to tell from the official information which SOEs have fulfilled this prediction of decline and which have not. With any measure of performance the question that is hard to answer is - compared with what? Economic-valueadded analysis is not used as thoroughly and transparently as it should be so that the returns on capital cannot be benchmarked easily with the private sector. Further, it is especially difficult when the government has made decisions that particular SOEs are to do things they would not do if they were strictly commercial, and the costs of these are not measured and published.

Privatisation allows for there to be a contest for control of business assets, which is a crucial element of the processes of evolution in the economy. Allowing this process to work is the central reason for privatisation, as it enables boards and managers to compete for the right to manage business assets. Having ministers set business strategies monitored by officials is the alternative, but it is nearly impossible to contest effectively their views of how well they are doing unless they are obviously doing badly.

The transition to long-term holding of business assets that long-term holding requires a shift in the SOE model. This is encouraging, but will it address the inherent weaknesses in public sector processes of governance? These include patronage appointments, advice and monitoring from officials who are not necessarily skilled in commercial analysis and decision making, ministers with very short-term horizons, and noncommercial incentives influencing longterm business strategies. SOEs report that the policies of long-term holding are largely about deeper intervention into their affairs. We shall see in time what the effects of this are on performance, but this will be difficult, as we will never know what the lost opportunities were.

Over the 25 years since the original conceptual work on SOE policy there has been an explosion of research, theory and practice on corporate governance, management and performance, known to the initiated as the economics of organisational architecture. This considers, firstly, the question of how to co-locate business decisions with the best information and capability, and, secondly, what are the appropriate internal controls to establish performance requirements, information and incentives so that strategies are implemented. The first is about how a firm manages the external markets for capital, managers, employees, suppliers, technology and so forth. The second is about regulating internal markets. I agree with Rob Cameron's view that the current SOE model looks very flawed from the perspective of this literature, in relation to the relationships between boards, ministers and their officials (see Cameron, 2005). In some 
cases the boards are in effect largely advisory, while their members carry huge risks to their reputations as business professionals while being paid a fraction of what they earn with the same skills in the private sector. Is this compatible with long-term business success?

The government's advisers on SOE policy displayed a lot of confidence in their 2005 briefing to their ministers that they have plenty of talent available and provide training for prospective and newly appointed directors. However, I would have thought that the senior and experienced directors required to govern these companies would not need a lot of training. I am sure these inhibitors are keeping a lot of people away, whose skills are necessary to maintain high performance in these companies.

Many of these directors have several government appointments and no significant private sector appointments. Some of these appointments are plainly the result of political patronage. Is there a risk of getting a cadre of public sector directors who lack much other relevant experience and are acculturated into accepting a level of overt and covert ministerial intervention that is not consistent with the governance requirements for business success in the longer term?

A survey of directors of the largest state enterprises "suggests that SOEs are potentially at risk from an appointment process which virtually guarantees relatively high turnover among directors and limited engagement by chairs and directors in creating boards with the balance of skills needed for effective governance. Directors are concerned that appointments made for political or diversity reasons may be reducing their ability to assess long-term strategy ..." (Norman, 2006). The overall conclusion from this survey is that there is considerable room for improvement in the government's long term hold strategy.

A thoughtful and rigorous approach to what business assets the state should create, buy or sell from a public policy perspective should be a continuing process. For the present it seems that there are ideological prohibitions on such work. The head of the Accident Compensation Corporation was recently called to account for having discussions about private accident insurance, even though private provision was in place under the last government and might be again. Surely in the strategic planning of state organisations there should not be a prohibition on thinking about possible future policies that are not those of the present government. The portfolio of business assets seems stuck in a time warp.

With privatisation off the agenda for those enterprises where there is a substantive reason for public ownership, there is a case for a policy of partial sell-down of shares to get better shareholder monitoring through having a price quoted on the stock market and a greater attractiveness to a larger number of highly skilled commercial directors.

Air New Zealand is not an SOE but a public company in majority public ownership. The shareholder can influence strategy and direction only through the means established in general company law. These are far less at risk of illconsidered interventions by state officials than SOEs. The Air New Zealand model looks to be superior for enterprises in which the state wants to be a long-term shareholder than the SOE model. It is more robust and transparent about its relationships with the state, which experience shows is good for governance and performance over time.

\section{Hospitals}

We can see in the public record performance problems in hospitals in terms of the volume, cost and quality of services, and the appropriateness of those services to the demands and needs for them. Full and consistent data on hospital services' volumes and costs are not available and so the evidence is patchy - but not encouraging. The main conclusions of a February 2005 Treasury report, released eventually under the Official Information Act, were that (allowing for limited data available and recognising various conceptual issues):

1. Real (CPI-adjusted) hospital expenditure in 2003/04 was $13.4 \%$ higher than in 2000/01, whilst measured hospital outputs were $4.7 \%$ higher. On the basis of these figures, hospital efficiency would appear to have fallen by $7.7 \%$ $(2.6 \%$ p.a.) over the last three years.

2. Over the previous three years (1997/98-2000/01), the same approach suggests that hospital efficiency increased by $1.1 \%$.

Much of the additional expenditure went into wages set in settlements that were beyond the control of the district health boards (DHBs), and were simply passed on in demands for more money from the budget. The report notes that the DHB sector as a whole and individual DHBs are not set clear expectations in relation to productivity or efficiency improvement.

But the rapid growth in expenditure combined with such volume and productivity data as are available, together with the continuing stress to at least some DHBs in meeting their budgets, points to the need for a much improved effort in assessing and benchmarking trends in hospital volumes and costs. It is disappointing that there seems to have been some resistance to doing this, as evidenced by the sporadic availability of data.

Turning to the quality of hospital services, the public record is - or at least was until the meltdown at Hawke's Bay - dominated by the enquiry into the death of a patient under the Capital Coast District Health Board (CCDHB) 
and the request of the health and disability commissioner for assurances that around the country systems were in place to ensure that such an incident would not occur again. A review of the responses to the commissioner's request to all DHBs produced the following comment:

The DHBs seemed to fall into one of three categories - those that really understood what a safety culture was and demonstrated systems thinking (e.g., West Coast DHB and Canterbury DHB), those that superficially used the language of safe \& quality care but their action plans did not give confidence, and those that have not really moved on from the individual blaming culture - they continue to believe that if doctors just concentrated harder, worked harder and were more careful, then medical errors would not occur. This is at variance with the literature over the last 10 years, which identifies that the practice of medicine is a complex adaptive system, that humans make errors (even experts trying hard), and that a safe system predicts errors and sets up defence systems to prevent errors impacting on the patient. (Seddon, 2007, pp.5-6)

The policy of DHBs being bulk funded - strangely, at a time of vociferous opposition to bulk funding of schools, for which I think it was better suited - sought to increase local control and accountability, better integrate primary and secondary care at the local level and save administrative costs. There has been no comprehensive evaluation to see the results to my knowledge, but I would have questions about the appropriateness of these arrangements to best address these issues of volume, cost and quality. As the commissioner has noted, the sector is too fragmented to deal with the quality problem. I find it hard to see how to get better control over costs and volumes without return to some system of purchasing on a service basis rather than bulk funding. The technology for doing this is not simple and cannot hope to be duplicated in $21 \mathrm{DHBs}$, when four regional health authorities were finding it hard going in the mid-1990s.

The major attraction of bulk funding seems to be that it makes it easier for ministers to argue with a hospital in financial trouble that it is getting the same resources for its population catchment as other hospitals. While there is merit in this, and it provides a valuable benchmark, it glosses over differences in the costs of services between hospitals for various reasons, and assumes that each hospital can offset its more expensive services against its cheaper ones when the information to validate this is now mostly missing. The consequence of the way the system works is that the government intervenes in pay fixing, on the one hand, and sets budget caps on the other. Some hospital managers then find themselves unable to meet commitments that are part of government policy, especially in the area of elective surgery.

Thus, it appears that a considerable number of staterun hospitals not only are poor on quality, but do not know what quality management is about. The data do not seem good enough yet to resolve different perceptions about how these statistics compare with international benchmarks. But, regardless, these comments by the commissioner suggest that they should be much better.

The health and disability commissioner has stated that little has changed since 2006 (Hazelhurst, 2008), when two quality experts said New Zealand hospitals were 'not acceptably safe'. When asked what the impediments to quality were, the commissioner, Mr. Paterson, said a major obstacle was that New Zealand had 21 different boards each doing their own thing: 'We lack co-ordination and actually some direction in these things. I think we have an unduly complicated system for four million people.' DHBs needed to share ideas so that they could 'stop reinventing the wheel'.

Problems in coordination may also underlie the weakening in control of costs and volumes of services, which the Treasury paper clearly shows coincided with the abolition of the Health Funding Authority, which I should declare I chaired.
The lack of management information leaves it a mystery to outsiders what is the deeper source of the problem. But the symptom is real enough and can be seen, for example, in the Capital Coast district where, in October 2007, there were 70 people who had been on waiting lists for more than six months and who had the necessary points to qualify for treatment within that period.

The recent publication of data on 'sentinel' incidents in public hospitals is a step forward. But why has it taken so long to publish essential information on the quality of care? The chair of the Quality Improvement Committee said that it was because the reforms in the 1990s were all about efficiency and discouraged sharing of information and cooperation between professionals. ii This doesn't gel with the fact that in the 1990s the points system for bookings for elective surgery was developed in a collaborative forum more intense and successful than anything seen yet around hospital quality under the DHB system. More worrying is the implication that collaborative behaviour and transparency is, in the mind of a senior health official, inconsistent with striving for efficiency.

I suggest that the time is long past for casting in ideological 
terms the tension between efficiency and performance, on the one hand, and trust and public spiritedness and cooperation on the other. We shouldn't accept that we cannot have both. A recent book by Julian LeGrand (2007) characterises philosophies of public management in terms of:

- trust;

- command and control;

- voice; and

- choice.

He weighs up the strengths and weaknesses of each and argues that expanding the opportunities for choice not only serves the interests of the less well off, but also makes the other methods work better. It is also what these people say they want. It is insightful to ponder the oft-repeated comments about the dangers of giving citizens choice as exemplified by the quote above from the chair of the Quality Improvement Committee from the perspective of LeGrand's book.

Why, because a citizen might exercise a choice to avoid going to a hospital with a poor quality record, would the clinicians there not cooperate with those in other hospitals to work on improving the quality of their services? Citizen choice inevitably means competition between alternative providers, which has become a bad word in state sector discourse. Solutions are typically seen in more 'coordination' by the elite running the monopoly.

But the mystery about the view from the Quality Improvement Committee is why providers in public sector organisations should resist cooperating to share quality improvement practices once they face the possibility that their patients might have an expanded choice of who to get the treatment from. There are plenty of reasons and evidence why people in competition might cooperate when they are all employed by the state, and even with private sector hospitals. Many doctors work in both sectors. I think the argument should be seen as evidence of another phenomenon no one talks about any more: capture of policy and resources by interests within the state providers. There is an imbalance of influence between producers and citizens.

From the outside it appears that the central authorities are having trouble dealing with these issues. The expectation seems to be that by sacking board members, changing chairs and spending more money, everything will come right. The minister of health's response to the announcements about quality and safety issues was to write a letter to the boards, which will already have a file of such letters going back many years. I doubt that such responses are adequate to the problems. I was surprised at the minister of health's announcement before Christmas that he has given the revised CCDHB four months to rectify things or he will appoint a commissioner. The new chief executive was not due to start until mid-April. These problems have been around for 20 years and cannot be fixed in four months. All the simple explanations for the problems were examined closely by the previous board and dismissed; only the hard ones remain. The evidence from the commissioner's report referred to above shows that the problems are deep in the fabric of the organisation.

Also, it is surely a strange arrangement to have people who are elected by the citizens told that their job is to implement government policy and that they are not allowed to share their views in public with the people who put them there.

All health reforms are about reallocating functions and responsibilities between politicians, governors of health authorities, bureaucrats, auditors and monitoring agents, managers and health professionals. They are also about engineering structures of relationships between these and the communities and individuals they serve.
Where might the authorities look for proposals to adjust these in ways which promote solutions to these so far intractable problems? I agree with the commissioner that the balance of what is done centrally and locally is wrong, leading to apparent problems of leadership and coordination. I think it is insightful that companies that own chains of hospitals generally use franchising arrangements, in which approaches to quality and many aspects of administration and management information are centralised, while the hospitals themselves are run locally, often with strong professional leadership. With this template in mind I think it is worth investigating whether some functions that have been decentralised would be more effectively centralised. Trying to solve the quality issues through leadership, writing letters and sharing experiences is unlikely to be as effective as an astute mix of centralised and decentralised approaches within a common strategy.

A deeper evaluation of the options for addressing these problems in state hospitals would freely examine the possibility of hospital and other services for the sick and disabled being provided in a similar fashion to the services that are acquired for accident victims through the Accident Compensation Corporation. In other words, I am suggesting a return to a separation between purchasing and provision of services.

The current situation in the provision of hospital services illustrates nonconformity with several of the key performance principles of effective public management I began with. In the public record are authoritative opinions in support of my proposition that these problems are associated with weaknesses and instability in governance arrangements, lack of clarity in roles and responsibilities, poor information, weak accountability arrangements and distorted incentives.

\section{Some cross-cutting issues}

In this section I include some issues that are not about specific policy areas but are issues about capability that cut across the policy areas. 


\section{The professional public servant and free and frank advice}

The tradition of a politically neutral public service and a codified relationship between it and ministers is embedded throughout official documents on the topic. One of the duties of this relationship is for public servants to give what is colloquially known in shorthand as free and frank advice.

The Cabinet Manual says that:

members of the public service: are (as appropriate) to give free and frank advice to Ministers and others in authority, and, when decisions have been taken, to give effect to those decisions in accordance with their responsibility to the Ministers or others.

The Public Service Code of Conduct says that the duty of a professional public servant includes:

- preparing advice, delivering services, and reaching decisions by using analytically sound, well-rounded, informed and inclusive approaches; and

- tendering that advice when required, with objectivity, courage, tenacity and independence. (SSC, 2007)
Lawyers have a duty to the courts, doctors have duties to their colleges, and many professions are bound by ethics and disciplinary processes. A lawyer in the Justice Department is bound to fulfil the duties of a member of the legal profession as well as those of the State Sector Act. All public servants, whether they belong to a structured profession or not, surely have an ethical obligation to do the right things and to speak up within their organisations, or even, in extreme situations, blow the whistle publicly. These duties are not reliant on permissions or requirements in official documents.

Further, I believe that the duty of public servants to bring forward well-researched advice with frankness has even deeper roots. Much of my work these days is with governments whose business is not conducted in English, which clearly distinguishes the meanings of the words politics and policy. Many languages do not. One word is about power while the other is about truth. Western liberal democracy has embedded this distinction in its public institutions in a wide variety of constitutional and administrative arrangements. One of these is the professional public service, which, following British precedent, goes back to the Northcote-Trevelyan recommendations of 1854 to end the patronage system of public administration. In his 1861 Representative Government, John Stuart Mill wrote in connection with these reforms, which he supported, that he thought that the effective conduct of representative government required administration by educated and orderly minds. New Zealand inherited these arrangements and these beliefs.

While republicanism in New Zealand may not be inevitable, it seems probable. I argued at an Institute of Policy Studies (IPS) conference on the constitution, on its possible content, that it should provide for a public service that is based on principles of professionalism, managerial excellence, effectiveness, political independence, public service ethics and loyalty to the government of the day, and that has adequate resources to do all this (see IPS, 2000). This suggestion is based on a belief that these things should not be taken for granted, and that, based on our experience, they are essential for an effective and responsive state for New Zealand.

Whatever the formalities, for any senior public servant in any era the space he or she has to provide free and frank advice is earned rather than granted or conventionally accepted. I think the emphasis in SSC documents on building trust is crucial because, in my view, a politically neutral and highly competent public service contributes to holding the ship of state upright regardless of where the helmsperson is steering it. It is, perhaps, a controversial view that the public service has a constitutional position, but it follows from my concern that New Zealand lacks sufficient constitutional checks and balances on its government and Parliament. As an illustration, remember the antiterrorism legislation that intruded into the most sensitive rights of the individual in 
relation to the state. This put the police in a no-win situation, and the solicitor-general said the legislation was not capable of supporting a prosecution. No one has taken responsibility for this - not the prime minister, not the select committee, not any official. It showed that a vital check on the powers of Parliament is missing.

On the subject of the political neutrality of the civil service, it is arguable that the 'Washminster' system is appropriate in some countries, whereby all departmental chiefs are subject to removal or reappointment when the government changes - although most keep their jobs. But I think it is more suited to countries that do have the necessary checks and balances and the depth of human capital to have competent 'governments in waiting'. But as New Zealand seems to be short of talent across the board, I do not think the threat to capability and consistency that this would raise is worth the risk. Besides, the designers of the State Sector Act put in the necessary clauses that permit a government to insist on particular appointments if they do it transparently. If a government is convinced it needs a particular individual in place to get a job done, then it has the means to do so.

\section{Official information}

The more that sensitive advice is exposed in public, the more the officials who provided it will be called on to explain or even defend that advice in public. This can create tensions with ministers that are corrosive to the working relationships. It is better that sensitive advice is well presented and given than it is not presented in order to preserve the relationships. Some rebalancing of the objectives of the Official Information Act (OIA) might be in order to help promote the flow of frank advice. But while I would be sympathetic to a bit more protection to advice, which, if made public, could damage working relationships, I see the bad habits of some officials who seem to think their duty is protecting their ministers from hard questions in the House by resisting the release of factual information that should be readily available. It took MP Heather Roy many months to force out information on how many people had died on hospital waiting lists. Such information is not advice and I would favour a legislative basis for requiring officials to publish information bearing on the performance of public institutions - starting with health. It is good that the chair of CCDHB has promised that his organisation will no longer stonewall requests for information, but this needs legislative backing.

That all is not well with the OIA is clear from the analysis of experience with it undertaken by Nicola White (2007). Her central conclusion is that a law that was meant to promote trust is achieving the opposite. She wants the caseby-case approach to be augmented by rules and guidelines and consistent practices to better align the expectations of the parties to a request for information. That would be hard to argue with.
Professional public servants should also be reticent about spinning information and leave that to ministers and their press staff. My attention was caught by a Labour Department spokeswoman on Radio New Zealand in early February 2008 who said she was 'excited' and 'very pleased' over 'fantastic pieces of news' in the latest release of employment statistics, emphasising the positive. iii This person speculated wildly about the behaviours of labour market participants and went on to offer such opinions as that 'we need to make sure we are not creating jobs at the lower end' - whatever that means in terms of the public policy advice the Department of Labour might be offering the government. Given the large and growing number of communications staff employed by ministries, too much of this kind of news release would be a worry for the independence of the public service.

\section{Joined-up government}

Getting agencies to work together is a difficult challenge anywhere, but New Zealand seems to stand out in the endless emphasis that has been put on this for 15 years. What has been learned about why it is so difficult? A recent paper in Policy Quarterly emphasises that this is being seen now as being about horizontal accountability and responsiveness to citizens and vertical accountabilities are being de-emphasised in the search for joined-up government (Gill et al., 2007). There are limits to how far vertical accountabilities can be sacrificed. As the controller and auditor-general said in 1989:

The requirement to act within one's lawful authority has special implications for those responsible for the management of publicly provided resources. Put simply, the Government and its departments cannot do anything they want! (see Martin, 1991, pp.6, 13)

Are there insights emerging on how to judge how much coordination and stakeholder consultation is enough? Some coordination can be expensive and distorting. I have seen in one situation the leader of a crucially important public service bogged down in pointless meetings with other public servants who had nothing to contribute. This particular chief executive was criticised in his performance assessment for being too focused on being the best in the world at this service and not participating sufficiently in whole-of-government and collegial activities.

Are there reasons for concern that the mechanisms for coordination are stifling opinion and open debate? If ministers control who or which agencies will be on what committees, then they can control the advice they get. They can even ensure they get none if they prohibit advice coming 
up unless it is agreed to in consensus. For example, if you were to ask the Treasury and most large spending ministries to agree on papers on improving cost effectiveness in spending, there would be very little advice on the subject - just as joint reports on SOE policy were unachievable in the mid-1980s. Sir Geoffrey Palmer was alert to this as prime minister and should be brought to ministers to resolve.

One possible example of this problem in action is the fact that it has taken years for officials to get seriously into work on carbon trading. This is now happening through a coordinating committee, at least one of the members of which cites it as a fine example of joined-up government. But in the background is the fact that the carbon trading became an inside game for the government and its SOEs when the government expropriated the carbon rights over Kyoto-qualifying forests. The private sector participants wrote off their investments in getting the trade going years ago because the government created such uncertainty over the property rights that there was doubt over what they had to sell. A considerable potential value to New Zealand was thereby lost years ago, and I am aware of no official advice to that effect at the time. insisted that if officials had non-trivial differences, then those

shrinking real resources. A major change following the earlier reforms was that organisations took responsibility for managing within their budgets. After several years of rapid expenditure growth, is this discipline sufficiently strong to enable this collaboration to succeed? We must hope so.

In the quest for more focus on outcomes and wholeof-government responses, has concern for efficiency and economy been given too much of a back seat? Was the capability of the public sector really run down so far that we needed to add a number of civil servants roughly equal to the entire global employment of the World Bank?

Obviously, new prisons need staffing, and KiwiSaver need administering, but there are always new things coming along. Where are the gains from doing things more efficiently and cheaply? Was there nothing to cut back? How do you explain the huge increases in staff numbers in the Ministry of Health when the policy was to devolve responsibility to DHBs, which absorbed most of the functions of the Health Funding Authority?

What would a change to the budget system look like that links it more tightly into the whole public management system and supports a drive for delivering both good outcomes and cost effectiveness? Such a system would embed information about effectiveness and efficiency into the budget process. I don't think this happens today. What would you think about the Treasury becoming more like an adviser to the government on what to invest in and what to disinvest from on the basis of cost effectiveness? This would require a richer dialogue with spending ministries and

\section{Efficiency and effectiveness, strategy and budgeting}

The SSC documents report that transformation of the state services around the new strategic objectives is all going according to plan and real progress is being made. That's very exciting and a credit to those involved. These are important goals to achieve. So is the emphasis on client service, deepening networks and increasing capability in the Treasury.

But joining the dots around my questions might suggest that there is another, parallel reality, in which parts of the state administration are gobbling resources with insufficient concern for efficiency; that they are careless in managing services and clumsy in the way they define problems and craft solutions; that a lot of extant policy experiments are due for evaluation and reworking; and that too many people are complacent about things they should worry about. In that reality, the extant strategies for developing the state sector look like the guns of Singapore - pointed away from where the enemy is coming from.

I can't see much that gives any assurance that anyone is taking responsibility for thinking about these questions. The only tiny black cloud in the State Services Commission's statement of intent is a reference to how the economy has sustained an expansion of the state as a share of GDP that may not continue, and it is working with Treasury to get agencies to continue to deliver expected services with
Crown entities, leading to advice to the minister of finance about what strategies and business plans deserved financial support and how much. While I said in relation to SOEs that I have reservations about the Treasury doing this in relation to commercial businesses in competitive markets, I'm sure there are real gains to be made if it could do this proficiently in relation to nonmarket services.

The strategic documents, statements of intent and supporting materials of public institutions are today very impressive compared with what they were before the reforms. But many are vague and rather timeless. Some overreach their real mandates to describe specified services with grandiloquent visions of their contribution to the nation. I suspect that ministers don't get much involved in preparing many of them and see the real action somewhere else. This is a pity because I also suspect that a lot of deadweight administration cost from arguments over small things might be lifted if there were more agreement at a strategic level about what matters, what it costs and what plans are worth investing in. Obviously, ministers would need to engage in this - as in my experience the most capable among them once did, and perhaps still do. 


\section{Conclusion}

In each of these cases the diagnostics might lead the government to try to make existing systems operate better, or to change those systems. Crudely expressed, the overarching objective would be to strike a more harmonious balance between policies to promote economic development and policies to protect the vulnerable and some measures of redistribution. This at least is what I think professional advisers should have on their minds. This will bring them at times into conflict with politicians whose motivations are to gain and maintain power to implement their programmes.

To paraphrase the political philosopher and former bureaucrat Ralf Dahrendorf (1988, p.16), no society can be regarded as civilised which does not offer both provisions and entitlements. People need access to markets, politics and culture in the sense that they need 'chances in life' to make choices from a universe of diverse possibilities. The issue confronting all countries is how to create sustainable economic improvement in global markets while not sacrificing the basic cohesion of their societies or the institutions that guarantee liberty. For Dahrendorf, the question of how to create wealth and social cohesion in free societies may be the same everywhere, but the answers are manifold (Dahrendorf, 1999). This observation is as relevant in New Zealand as anywhere.

The relevance of this to my topic is that I am proposing that the state will be performing better or worse according to how well it is doing in terms of dealing with Dahrendorf's issue. A great state successfully identifies, minimises and balances these social conflicts where they arise. A poor state does neither provisions nor entitlements well, and allows the instruments of state coercion to be captured by sectional interests and bad ideas. In Dahrendorf's view, this conflict is never over in a western democracy, so the search for better solutions is permanent.

New Zealand's reforms, upon which this conference is reflecting, were about reforming the institutions of the state, by ministers and advisers who hoped to strike a better balance of this kind. The goals for fiscal policy and financial sector stability, which it is easy to downplay today, were actually achieved, while they struggled to redefine social policy first through targeting, and then back to more universality. Government reform in New Zealand did achieve efficiency improvements in formerly government-run businesses. Public sector reforms did actually achieve much of what the politicians who put them in place expected them to do in terms of contributing to fiscal policy correction, shifting the priorities of government expenditure and greater efficiency. These were very difficult economic times and two unlucky governments acted boldly to address them. But then new agendas took over.

Each of you will have your own views on the results of those reforms, but I suggest to you that the challenge faced by this generation of ministers, advisers and managers remains, as Dahrendorf argues, the same.

Each of you will have your own agendas for the future, but I hope I have persuaded you to think not only about how to improve your corner of the state, but about how you will do this in a way that addresses the balance of entitlements and provisions. The economist Arthur Okun coined the phrase 'the big tradeoff' in his 1975 book of the same name, Equity and efficiency: the big trade-off, to capture the fact that policies to promote economic growth often conflict with policies to promote equitable distribution of the fruits of the economy. He was not arguing that one should take precedence over the other, but that pursuing one often had costs in terms of the other. The ceaseless task of the modern state is to find policies and build institutions that ease this trade-off to the greatest extent possible so that a nation gets the best it can of both. I doubt that we are doing that.

To conclude, I will try to put down the questions and comments that Okun's and Dahrendorf's insights might imply about the cases I have noted here. I will add some questions that flow from the conclusions I summarised from my earlier study of New Zealand about the foundations of successful public management, and which I listed at the start of this article.

1. Why, when the state has taken onto itself a 'hands on' role in growing the economy and distributing the benefits fairly, doesn't it have a clear and unequivocal focus on the most important indicator of long-term prosperity: the productivity of resource usage? The government cannot distribute what economic agents have not earned.

2. If productivity has to grow faster than Australia's for us to close the income gap over time, then why does the Commerce Commission regulate the gas pipeline industry in a way that sacrifices efficiency in the use of these resources in order to redistribute wealth from the owners to the users of the pipelines? Have the latter become welfare beneficiaries? Liberal economists since Adam Smith have objected to business welfare, as it damages national prosperity.

3. Why, in the face of centuries of evidence to the contrary, do we believe that a government can make important property rights dependent on one's powers of persuasion with a minister or a tribunal and not cause a decline in the willingness to invest?

4. Why do we have such prejudice against providing choice to citizens about who they get state-funded essential services from, and insist that they buy them from state providers? The evidence is that low-income people value choice; why deny them? Could this be the late and unlamented concept of provider capture of government policy making a comeback?

5. What are we learning from the hard edges of accountability about clarity in roles and other matters, as, for example, from the current experience with the Hawke's Bay DHB?

6. Dreary as the prospect will seem to many people, is there a need for a further reform of the health system to rebalance what is controlled at the centre and what is delegated and how, and to allow greater choice?

7. Is there a need to change the OIA to strengthen its protection of high-level sensitive advice and remove its 
protection entirely from routine performance information on state organisations?

8. New Zealand seems critically short of high levels of talent for directors, managers, ministers and policy advisers: is there anything more we can do to raise the national capability in these respects?

9. Do we have the roles, relationship, skills, processes and levels of trust right between the three central agencies to forge an effective leadership group to drive the state to higher levels of performance?

10. What lessons and guidelines have been learned from 15 years of attention to whole-of-government responsiveness, and has there been a cost in terms of stifling the initiative of individual agencies?

11. What have we learned from the creation of megadepartments as regards incentives, information, cost and performance?

12. Why is world-class policy analysis and evaluation sporadic?

You will have other questions, and not all share the same answers to these ones. To return to the question in our conference theme of what comes after the reforms: the answer is more reforms. Successful states do this incrementally and continually without fuss, while weaker states do it periodically under pressure and with a lot of fuss because they have let things drift.

Those earlier reforms radically decentralised the way the state organised service delivery. In recent reforms, ministers have reached deeper into the affairs of these decentralised bodies, so we may now have a hybrid, with a mismatch of accountability and responsibility. But, when fixing the flaws in the system, remember that successful public sector management reform movements are designed to fulfill a larger policy or political purpose. Reforms for their own sake always founder for lack of sponsorship.

So the questions for this generation of state servants are: what are the critical challenges facing the country that you are taking some responsibility for? What are the reforms you will recommend to meet them? And what principles and lessons from experience will you draw on in forging this advice?

\footnotetext{
I am grateful for information and from discussions on various aspects of this paper with Rob Cameron, Don Hunn, Alastair Bisley, Bryce Wilkinson, Roger Kerr, Lew Evans, Bronwyn Howell, Lynne McKenzie, Alf Kirk, April Harding, David McGee, Claudia Scott, John Palmer, Keith Turner and John Martin. Responsibility for the content is entirely mine.

'Nine to Noon', Radio New Zealand, 20 February 2008.

iii 'Checkpoint', Radio New Zealand, 7 February 2008.
}

\section{References}

Cameron, R. (2005) 'Government in business: the evolution of the SOE model', http:// www.cameronpartners.co.nz/media/files/ Government_in_Business_Evolution_of_SOE_ Model_TVH\%20Chapter_20050614.pdf

Commerce Commission (2004) Gas Control Inquiry: Final Report - public version, Wellington: Commerce Commission, Wellington, http://www.med.govt.nz/ upload/14198/final-report.pdf

Dahrendorf, R. (1988) The Modern Social Conflict: an essay on the politics of liberty, London: Weidenfeld and Nicolson

Dahrendorf, R. (1999) 'The third way and liberty', Foreign Affairs, 78 (5), pp.13-17

Gill, D., E. Eppel, M. Lips and B. Ryan (2007) 'Managing for joint outcomes - the breakthrough from the front line', Policy Quarterly, 4 (3), pp.39-42

Hazelhurst, S. (2008) 'Hospital patients not safe - commissioner', Dominion Post, 13 February

Howell, B. (2007) 'A pendulous progression: New Zealand's telecommunications regulation 1987-2007', Wellington: New Zealand Institute for the Study of Competition and Regulation Institute of Policy Studies (2000) Building the Constitution conference, Legislative Council Chamber, Parliament Buildings, Wellington, 7-8 April

LeGrand, J. (2007) The Other Invisible Hand, Princeton: Princeton University Press

Martin, J. (1991) Public Service and the Public Servant: administrative practice in a time of change - essays, Wellington: State Services Commission

Norman, R. (2006) 'When the "for sale" notices are withdrawn: how should stateowned enterprises be governed', Public Sector, 19 (1), pp.3-8

Scott, G. (1999) 'The 1999 papers', paper presented at the ninth Public Service Senior Management (PSSM) conference, Wellington, 30 September, http://pssm. ssc.govt.nz/1999/papers/gscott.asp

Scott, G (2001) Public Management in New Zealand: lessons and challenges, Wellington: New Zealand Business Roundtable and Australian National University Press, http://www.nzbr. org.nz/documents/publications/ publications2001/public management.pdf

Scott, G., with D. Birnie, L. McKenzie and K. Murray (2004) 'Submission to the Commerce Committee on the Electricity and Gas Industries Bill', Wellington: LECG
Seddon, M. (2007) Safety of Patients in New Zealand Hospitals: a progress report, Wellington: Health and Disability Commissioner, http://www.hdc.org.nz/ files/hdc/publications/seddon-review.pdf

State Services Commission (2005) Development Goals for the State Services, Wellington: State Services Commission, http://www.ssc.govt.nz/dev-goals

State Services Commission (2007) 'Appendix 1: What it means to be professional in the state services - an outline of professional behaviour' in Understanding the Code of Conduct-Guidance for State Servants, Wellington: State Services Commission, http://www.ssc.govt.nz/code-guidancestateservants

Tasman Economics (2001) 'Regulatory impact statement review', Wellington: Ministry of Economic Development

White, N. (2007) Free and Frank: making the Official Information Act 1982 work better, Wellington: Institute of Policy Studies

Whitehead. J (2005) 'What could the Aussies possibly tell us about growth?', breakfast address to the New Zealand Institute of Directors, 28 June, http://www.treasury. govt.nz/publications/media-speeches/ speeches/growthaustralia/index.htm 